\title{
A POLICY PROPOSAL FOR HERITAGE LANGUAGE CONSERVATION: A CASE FOR INDONESIA AND SARAWAK
}

\author{
Bambang SUWARNO \\ Universitas Bengkulu, Indonesia \\ Jalan W. R. Supratman, Bengkulu 38371, Indonesia \\ wdsaraswati@gmail.com
}

Manuscript received 7 July 2017

Manuscript accepted 4 October 2017

\begin{abstract}
Heritage languages are declining in Indonesia and Sarawak. They need conservation due to their situations as endemic languages. Their decline could be attributed to the fact that they often do not possess significant roles in the public domains. As a result, their speakers see little rewards or prestige for maintaining them. In Indonesian and Malaysian constitutions there is a spirit for protecting heritage languages. However, their executions, through national laws, might not have provided adequate protection for the heritage languages. As heritage languages keep declining, a policy revision needs to be given consideration. A heritage language may better survive if it has some functions in the public domains. Thus, to conserve the heritage languages, there is a need for the revision of language policy, so that these languages may have roles in the public domains, with varying scope, depending on their size. Large regional languages may be given maximum roles in the public domains, while smaller regional languages may be given smaller roles. Language conservation areas could be developed, where heritage languages serve as co-official languages, besides the national language. These areas may range from a district to a province or a state.
\end{abstract}

Keywords: language policy, language planning, heritage language, language conservation

\section{Introduction: Why Heritage Languages Must Be Conserved?}

Before starting the discussion, it is essential to define heritage language. Valdez (2005) defines heritage languages as the non-societal and non-majority languages that are spoken by groups that constitute linguistic minorities. It is important to distinguish between migrant languages and indigenous languages. A migrant language is one that is a minor language in a country but comes from another 
country in which it may be a major language. An example is the Arabic language, which is a minor language in Malaysia, but comes from the Middle East, where it is a major dominant language. In contrast, an indigenous language is a minor language in a country and is not a dominant language in other countries either. It is the indigenous heritage languages that are usually threatened, and thus the discussion in the paper is limited to these types. In this paper, the term "heritage language", "local language", and "regional language" are used interchangeably.

Various reasons can be put forward for heritage language conservation. For example, it can be argued that heritage languages are precious. However, a counter argument can be forwarded that the cultivation of heritage languages may hamper the cultivation of the required national language. However, there is a factual reason that all parties may agree with, that is, that various heritage languages in the world need conservation due to the fact that they are endemic languages. This is particularly true in South East Asia. For example, in Indonesia, apart from the Malay dialects, other languages practically only exist in the country. For example, according to Ethnologue (2017), the Javanese language, the largest heritage language, has $84,368,500$ speakers. However, almost all of its speakers, i.e., $84,300,000$ (>99\%) speakers, are found only in Indonesia, especially in the Java island. The remaining Javanese speakers are in Suriname and Malaysia. With respect to other languages, almost all of their speakers are only found in Indonesia, with very few speakers outside the country.

According to Ethnologue (2017), Sarawak also has a number of heritage languages, for example, Bidayuh, Iban, Madang, Melanau, and Sebuyau. The same source also reveals that all of the languages are practically endemic. For example, the number of Iban language speakers is 415,000 , of which 400,000 live in Sarawak. The Melanau language speakers number 30,099 , of which 28,899 speakers also live in Sarawak. This endemic situation brings an important consequence; that is, if a regional language in the area becomes extinct, the language will disappear completely.

\section{Factors Attributed to the Decline of Heritage Languages}

The decline of regional languages seems to be a common phenomenon. Brenzinger (1997) states that there is an increasing trend among non-dominant language speakers to raise their children in the dominant language and leave the mother tongue.

Crystal (2000) attributes the decline of regional languages to two common causes: (1) Physical hazards, such as war, famine, disease, and natural disasters; and (2) the shrinking domain of local languages. Crystal (2000) elaborates that speakers of these local language have little opportunity to use the local language, since the language is officially excluded from the public functions, such as public services, business or the media. Quoting from Fishman, Crystal (2000, p. 83) refers to this situation as "folklorization", where the local language of the area gradually disappears from a significant side of life and is used only in domains with lower benefits and prestige, such as popular art and folk stories. The loss of domains reduces their benefits and prestige; it also causes the loss of vocabulary, discourse 
patterns, and style ranges. Eventually, local languages may be abandoned because there is less vocabulary to facilitate the conversation.

Paulston (1994) observes that language speakers tend to shift to the dominant language, which has a function in the public sphere and give economic rewards and prestige. Paulston (1994) underlines the importance of benefits in language shifting. She states that prolonged contact between a regional language and the dominant language has three possibilities: (1) language preservation, (2) bilingualism, or (3) language shift. She argues that ethnic groups in a modern state, given opportunities and incentives, usually turn to the dominant language. The reason is that ethnic group residents want to participate economically, in order to obtain goods and services, in society.

This economic participation is facilitated if ethnic groups master the dominant language. For example, in Indonesia and Malaysia, education and work would be better facilitated for a citizen if $s /$ he masters the national language. Thus, if the mastery of the dominant language gives incentives, especially socioeconomic incentives, there is a growing motivation to shift to the dominant language. In addition, the lack of functionality to use the heritage language in the public sphere also diminishes its practice, so that its speakers lose pride in using it.

It can be concluded that a local language suffers a setback because it has no function in the public sphere. This lack of function causes the decline in the benefits and prestige of the regional language. As a result, the local language, which has served as the language of the family and the community, is gradually abandoned and its speakers switch to the dominant language used in the public sphere.

\section{Language Policy: The Present Situation in Indonesia and Sarawak}

Tollefson (1991) defines language policy as language planning by governments. Meanwhile, he refers to language planning as all conscious efforts to affect the structure or function of language varieties. Cooper (1989) distinguishes language planning into: (1) status planning, the effort to allocate the use of languages in the society in general; (2) corpus planning, which attempts to modify the body of the language; and (3) acquisition planning; which concerns the use of language in educational setting. The fundamental language policy is reflected in the constitution, whose stipulations are usually elaborated in the lower laws and regulations.

With respect to Indonesia and Malaysia, at the constitutional level, there is a spirit of conserving heritage languages. In Indonesia, Undang-undang Dasar 1945 (The 1945 Constitution) (2002), while underlining the position of the Indonesian language, provides heritage language protection, which is made explicit in the amended version.

Article 36

Bahasa Negara ialah Bahasa Indonesia.

[The state language is the Indonesian language.]

Article 32, Verse 2

Negara menghormati dan memelihara bahasa daerah sebagai kekayaan budaya nasional. 
[The state respects and conserves heritage languages as a national cultural heritage].

By comparison, the (Malaysian) Federal Constitution (2010) stipulates as follows.

Article 152

(1) The national language shall be the Malay language and shall be in such script as Parliament may by law provide:

Provided that-

(a) no person shall be prohibited or prevented from using (otherwise than for official purposes), or from teaching or learning, any other language; and (b) nothing in this Clause shall prejudice the right of the Federal Government or of any State Government to preserve and sustain the use and study of the language of any other community in the Federation.

However, while the constitutions provide considerations for heritage languages, there seems to be a problem when the constitutional provisions are executed through lower laws such as language in education.

Shaeffer (2004) underlines the critical role of education for the survival of heritage languages. UNESCO (cited in Mayor \& Binde, 2001), declare that merely introducing heritage languages as a subject for instruction is not adequate and that heritage languages need to be used as the medium of instruction.

In this respect, there might be a question as to whether the provision for heritage languages as the medium of instruction is adequate, both in Indonesia and Sarawak. In Indonesia, Undang-Undang Republik Indonesia Nomor 20 Tahun 2003 tentang Sistem Pendidikan Nasional [The Law of the Republic of Indonesia Number 20 Year 2003 on the National Education System] (2003), stipulates as follows:

Article 33, verse 1

Bahasa Indonesia sebagai bahasa negara menjadi bahasa pengantar dalam pendidikan nasional.

[The Indonesian language as the official language serves as the medium of instruction in national education.]

Article 33, verse 2

Bahasa daerah dapat digunakan sebagai bahasa pengantar dalam tahap awal pendidikan apabila diperlukan dalam penyampaian pengetahuan dan/atau keterampilan tertentu.

[A heritage language could be used as the medium of instruction in the early years of education if it is required in the transmission of certain knowledge and/or skills.]

The early years consist of only the first and second year of primary school. In the matter of language of instruction, the Education Act Malaysia (1996) states as follows: 


\section{Section 17}

(1) The national language shall be the main medium of instruction in all educational institutions in the National Education System except a nationaltype school established under section 28 or any other educational institution exempted by the Minister from this subsection.

To safeguard the heritage languages, Razak Report 1956 (as cited in Karunan, 2016, p. 20), stipulates as follows:

.... making Malay the national language of the country while preserving and sustaining the growth of the language and culture of other communities living in the country.

However, Rahman Talib Report 1960, as quoted in Karunan (2016), deleted the underlined provision and instead recommended that all primary schools, including those who previously had used the heritage languages as the medium of instruction, switched to use the Malaysian language as the medium instruction.

It is evident that the execution of constitutional provisions, into laws and regulations, might not have yielded adequate measures for safeguarding heritage languages. Therefore, it might not be a coincidence that various studies and observations in Indonesia continue to show the decline in regional languages. Errington (1985) observes a decline in the use of regional languages among the younger generation. Gunarwan (2001), Kurniasih (2005), and Subroto, Dwiraharjo, and Setyawan (2008) revealed the decline of the Javanese language. In Kurniasih's (2005) study, which took place in Yogyakarta city, a heartland of Javanese language and culture, most middle class parents, especially the mothers, did not speak the Javanese heritage language at home, and this disrupted the intergenerational transmission of the language. Similar trends were observed by Yadnya (2003) for the Balinese language, Sobarna (2007) for the Sundanese language in West Java, and Alamsyah, Taib, Azwardi, and Idham (2011) for the Acehnese language in North Sumatra.

In the case of Sarawak heritage languages, it seems that a similar process also takes place. For example, Coluzzi, Riget, and Wang (2013) observed the decline of the use of Biatah language among its speakers and a shift toward the use of the national language. Meanwhile, Ting and Ling (2013) observed that the domains of heritage languages were decreasing because the expansion of the standard Malay and Sarawak Malay. Mohamed and Hashim (2012) revealed that the Sihan language was under threat, because the nine criteria for language vitality, per UNESCO, are not fulfilled. Ting and Campbell (2017) assert that formal education, in addition to urban migration and intermarriages, bring about the decline in the use of Sarawak heritage languages. According to the Ting and Campbell (2017), formal education causes diglossia leakage, in that school languages enter the home environment, thereby reducing the intergenerational transmission of Sarawak heritage languages. Furthermore, even in areas in which a heritage language predominates, such as the Iban language in Sibu and Sri Aman, students are not allowed to speak the language in the school compound. Such a measure may constitute a negative language policy, 
which hinders the maintenance of heritage languages.

Reflecting on the Indonesian policy for heritage languages, Abdullah (1996) states that the promotion of national language is good because various Indonesian ethnic groups need a universal communication tool; however, it should not mean that the heritage languages are left to wither.

Meanwhile, Albury and Aye (2016) maintain that the Malaysian language policy, as reflected in its laws, consists of minimum linguistic rights in the educational system and that little effort is made to address the linguistic diversity in a more holistic manner.

These suggest that the current language policies in both countries may need reflection and possible revisions.

In both areas, heritage languages are largely absent from public functions. On the other hand, in their natural habitats, the home and community, they are being replaced by the national language. If this trend continues, the future of heritage languages might not be too bright. The fact that the present policy does not provide more functions for heritage languages may denote that the trend of heritage language decline might continue. In fact, Muhlhausser (1996) argues that most heritage languages in Indonesia might be extinct in a century.

\section{Language Policy Revision for Heritage Language: A Proposal}

It might be worthwhile to note a study by Barrena, Idiazabal, Junyent, Ortega, and Uranga (2006); the study shows the importance of official or co-official status, nationally or regionally, for regional languages. Based on an analysis of UNESCO's worldwide study of the local languages, they state:

It is to be noted that most of the languages that had declined were languages that did not have any official recognition. Similarly, of the languages that increased their number of speakers, $59 \%$ were official and $40 \%$ were coofficial. (p. 17)

Fishman (1991) states that what matters now is not simply to diagnose the decline of regional languages, but to analyse the causes and to find a solution. From the previous discussion it can be concluded that the assigning of public roles is necessary for local languages, in order that they may be sustainable. Through the roles in the public sphere, heritage languages can grow and provide reward and prestige for the speakers. The role in the public sphere for local languages can reduce diglossia leakage, that is, the intrusion of the dominant language the family and community (which hitherto have been the areas of use for the languages), because the speakers feel proud to use them.

Therefore, if local languages are to be preserved, roles are needed for local languages in the public sphere. Indeed, Kloss (1969) argues that indigenous heritage languages should be promoted throughout various policies.

It may be difficult to map uniform policies for different regional languages, because their conditions are different. There are large regional languages, with speakers from millions to tens of millions, and small regional languages, with 
speakers under a million. Nevertheless, one thing is evident; if heritage languages are to be conserved, a revision for the prevalent language policies need to be proposed. In this respect, Ting (2012) suggests that the elevation of the national language (in Malaysia) at the expense of other languages might not be feasible; instead, a policy that aims for equilibrium between various languages needs to be sought.

As a uniformed national/federal regulation for heritage language is may be difficult to establish, a local/regional approach may be more suitable. As it happens, the legal framework for the regional approach is available. In Indonesia, according to the Law No. 24 Year 2009, the development and preservation of regional languages become the authority of local governments. The Malaysian constitution provides special authority, which presumably include language policy, for the Sarawak state.

In this paper, a general language policy revision is proposed. Suwarno (2015) calls for a revision in the language policy, in the form of the establishment of special cultural and linguistic areas where local languages are given adequate public roles, accompanying the national official language. This may be established at a higher level (provincial/state level) or a lower level (district, sub-district, or village levels). For the principle of optimisation, the range of public roles that can be assigned to regional languages varies, depending on their size.

For a major heritage language, the following measures are suggested.

1. Major heritage languages should be given some public functions in special areas.

The national/federal official language continues to have the function of the national language. However, in other public functions (official regional language, language in the workplace, language of instruction in education language for wider communication), there should be a bilingual language policy, in which the national language and a major local heritage language can be used together in those functions. In still other public functions (language of literature and science and technology; language of mass media, language as subject), the bilingual language policy should also apply.

2. Diglossia leakage should be prevented.

In private functions (family language and community languages) the use of heritage languages should be encouraged. Moreover, it should be underlined that in the family, only heritage languages should be used, while the use of other languages is discouraged.

While the above proposal is affordable for major heritage languages, a similar approach may not be applicable for minor languages, for various reasons. Thus, the above approach might need to be downsized. For a bigger minor language, the coofficial status can be implemented at the district level, or even at sub-district level. In essence, this entails the formation of language reserve areas, similar to what is done to some Amerindian languages in America.

In Indonesia, for example, in Sulawesi island, the Bugis language is a bigger minor language. This language can be made co-official in some districts in which the majority of the population speaks the language. Similarly, in Sarawak, the Iban language can be adopted as a co-official language in some districts in which the majority of the local population speak the language.

For other minor languages, the approach adopted by India can be 
implemented. In the country, a lot of minor languages could be used as the medium of instruction at the first grades at the elementary education and the language of special mass media (Groff, 2004). For very small minor languages, even this might not be possible.

However, what can be done for all languages, big and small, is to prevent diglossia leakage, by retaining the languages as the family and community languages. After all, the family is the most important means of transmission of heritage languages from the older to the younger generation. Therefore, there is a need for regulations and encouragement to use heritage languages in the family, and possibly the community. The regulations can come in the form of regional bylaws, while the encouragement may come in the form of incentives for local mass media (e.g., radio station or local magazine) that have special broadcasts/texts in the languages.

\section{Conclusion}

Various regional languages are threatened with decline. This setback is caused by the absence of a public role for regional languages. Roles in public domains are essential as they give better rewards and higher prestige for the heritage languages and thus may provide the necessary motivation for their speakers to maintain the languages. In Indonesia and Sarawak, local languages are perceived to lack benefits and prestige, and thus are gradually abandoned by their speakers.

At present, the fundamental language policies, in Indonesian and Malaysian constitutions, provide protection or consideration for heritage languages. However, their executions, in national laws, might not have provided adequate measures for heritage languages. It is not surprising that heritage languages continue to decline. This situation suggests that policy revision may be beneficial.

The preservation of local languages may succeed if the local languages are given roles in the public sphere. The public roles may vary, depending on the population of speakers. For major local languages, the roles can be implemented at provincial/state level. These roles include almost all roles for the federal language, with the exception of the role as the national language. For minor languages, similar measures can be adopted, albeit in smaller areas or for a more limited scope. For all languages, diglossia leakage should be prevented; the family, and possibly the community, should be devoted as the habitats for the heritage languages.

\section{References}

Abdullah, I. (1999). Pendahuluan: Bahasa daerah menjelang abad ke-21 [Introduction: The heritage languages on the eve of the 21st century]. In I. Abdullah (Ed.), Bahasa Nusantara: Posisi dan penggunaannya menjelang abad ke 21 [The Nusantara languages: Their positions and uses on the eve of 21st century] (pp. 1-31). Yogyakarta, Indonesia: Pustaka Pelajar.

Albury, J. A., \& Aye, K. K. (2016). Malaysia's national language policy in international theoretical context, Journal of Nusantara Studies, 1(1), 71-84. Retrieved from https://www.researchgate.net/publication/304621880_Malaysia\%27s_Nation 
al_Language_Policy_in_International_Theoretical_Context

Alamsyah, T., Taib, R., Azwardi, \& Idham, M. (2011). Pemilihan bahasa Indonesia sebagai bahasa pertama dalam keluarga masyarakat Aceh penutur bahasa Aceh di Nanggroe Aceh Darussalam. [The choice of Indonesian as the children's first language in the Acehnese families who comprise Acehnese native speakers in Nanggroe Aceh Darussalam] Jurnal Pendidikan Bahasa Melayu [Malay Language Education Journal (MyLEJ)] 1, 31-44. http://journalarticle.ukm.my/3181/1/31-44_Artikel-

3_Teuku_Alamsyah_et_al.pdf

Barrena, A., Idiazabal, I., Juaristi, P, Junyent, C., Ortega, P., \& Uranga, B. (2006). The world languages review: Some data. In D. Cunningham, D. E. Ingram, \& K. Sumbuk (Eds.), Language diversity in the Pacific: Endangerment and survival (pp. 15-23). Clevedon, UK: Multilingual Matters.

Brenzinger, M. (1997). Language contact and language displacement. In F. Coulmas (Ed.), The handbook of sociolinguistics (pp. 273-284). Oxford, UK: Blackwell.

Colluzzi, P., Riget, P.N., \& Wang, X. (2013). Language vitality among the Bidayuh of Sarawak (East Malaysia). Oceanic Linguistics, 52(2), 375-395.

DOI: 10.1353/ol.2013.0019

Cooper, R. L. (1989). Language planning and social change. Cambridge, UK: Cambridge University Press.

Crystal, D. (2000). Language death. Cambridge, UK: Cambridge University Press.

Education Act Malaysia (1996). Retrieved from http://planipolis.iiep.unesco.org/sites/planipolis/files/ressources/malaysia_ed ucation_act_1996.pdf

Errington, J. (1985). Language and social change in Java. Athens, $\mathrm{OH}$ : Ohio University.

Ethnologue. (2017). Ethnologue: Languages of the world. Retrieved from http://www.ethnologue.com/country/ID/languages

Federal Constitution (2010). Retrieved from http://www.agc.gov.my/agcportal/uploads/files/Publications/FC/Federal\%20C onsti\%20(BI\%20text).pdf

Fishman, J. A. (1991). Reversing language shift: Theoretical and empirical foundations of assistance to threatened languages. Clevedon, UK: Multilingual Matters.

Groff, C. (2004). Status and acquisition planning and linguistic minorities in India. Paper presented at the Language development, language revitalization and multilingual education in minority communities in Asia, Bangkok, Thailand. Retrieved from http://www.sil.org/asia/ldc/parallel_papers/cynthia_groff.pdf

Gunarwan, A. (2001). The unstable state of the Indonesian-Javanese bilingualism: Evidence from language use in the home domain. Paper presented at the II Simposio Internacional Bilinguismo [II International Symposium on Bilingualism], Vigo, Spain. Retrieved from http://webs.uvigo.es/ssl/actas2002/04/08.\%20Asim\%20Gunarwan.pdf

Karunan, V.P. (2016). Malaysia: Language, education, and social cohesion. Paper presented at the $5^{\text {th }}$ International Conference on Language and Education: Sustainable Development through Multilingual Education, Bangkok, Thailand. 
Retrieved

from

http://www.Ic.mahidol.ac.th/mleconf/2016/Documents/PresentedFiles/Parall el\%20VI/T03E/T03E-2-Victor_P_Karunan.pdf

Kloss, H. H. (1969). Research possibilities on group bilingualism. Quebec, Canada: International Centre for Research on Bilingualism.

Kurniasih, Y. K. (2005). Gender, class and language preference: A case study in Yogyakarta. Paper presented at the 2005 Conference of the Australian Linguistic Society, Monash University, Melbourne, Australia.

Mayor, F., \& Binde, J. (2001). The world ahead: Our future in the making. Dhaka, Bangladesh: UPL.

Muhlhauser, P. (1996). Linguistic ecology: Language change and linguistic imperialism in the Pacific region. London, UK: Routledge.

Mohamed, N., \& Hashim, N. H. (2012). Language vitality of the Sihan community in Sarawak, Malaysia. Kemanusiaan 19(1), 59-86.

Paulston, C. B. (1994). Linguistic minorities in multilingual settings: Implications for language policies. Amsterdam, The Netherlands: John Benjamins.

Shaeffer, S. (2004). Language development and language revitalization: An educational imperative in Asia. Paper presented at the Language development, Language Revitalization and Multilingual Education in Minority Communities in Asia, Bangkok, Thailand. Retrieved from http://www.sil.org/asia/ldc

Subroto, D. E., Dwirahardjo, M., \& Setiawan, B. (2008). Endangered krama and krama inggil varieties of the Javanese language. Linguistik Indonesia 26(1), 8996. Retrieved from http://www.linguistikindonesia.org/images/files/EndangeredKramaandKramalnggil.pdf

Suwarno, B. (2015). Indonesian language policy and the views of Javanese language teachers in Yogyakarta: Implications for action (Unpublished doctoral dissertation). Curtin University, Australia.

Ting, S. (2012). Variable impact of Malaysia's national language planning on nonMalay speakers in Sarawak. Revista Brasileira de Linguística Aplicada, 12(2), 381-403.

Ting, S., \& Ling, T. (2013). Language use and sustainability status of indigenous languages in Sarawak, Malaysia. Journal of Multilingual and Multicultural Development, 34(1), 77-93.

Ting, S., \& Campbell, Y. M. (2017). The role of Indigenous languages in schools: The case of Sarawak. In M. Samuel, M. Y. Tee, \& L. P. Symaco (Eds.), Education in Malaysia: Developments and challenges (pp. 119-136). Singapore, Singapore: Springer.

Tollefson, J. W. (1991). Planning language, planning inequality: Language policy in the community. London, UK: Longman.

Valdez, G. (2005). Bilingualism, heritage language learners, and SLA research: Opportunities lost or seized? The Modern Language Journal, 89(3), 410-426.

Yadnya, I. B. P. (2003). Revitalisasi bahasa daerah (Bali) di tengah persaingan bahasa nasional, daerah, dan asing untuk memperkukuh ketahanan budaya [The Revitalization of heritage language (Balinese) in the competition among national, heritage, and foreign languages to strengthen cultural resilience]. 
Paper presented at the Kongres Bahasa Indonesia VIII [The 8th Indonesian Language Congress], Jakarta, Indonesia. Retrieved from http://staff.unud.ac.id/ putrayadnya/wp-content/uploads/2009/06/paperkongres.pdf

Undang-Undang Dasar 1945 [The 1945 Constitution]. (2002). Retrieved from http://jdih.pom.go.id/uud1945.pdf

Undang-Undang Republik Indonesia Nomor 20 Tahun 2003 tentang Sistem Pendidikan Nasional [The Law of the Republic of Indonesia Number 20 Year 2003 on the National Education System]. (2003). Retrieved from http://kelembagaan.ristekdikti.go.id/wpcontent/uploads/2016/08/UU_no_20_th_2003.pdf 